展 望

\title{
教室におけるコミュニケーション*
}

\author{
藤 崎 春 代**
}

\section{COMMUNICATION IN CLASSROOMS}

\author{
Haruyo FU JISAKI
}

\begin{abstract}
This article examined frameworks in which classroom communicatiom studies were done. Two lines of studies were made. One focusing on the interaction between teachers and students as the main medium of teaching: it was found to be desirable that utterances and their contents would be organized toward a structure of a whole lesson. The other line called ethnographic studies analysed details of communication qualitatively to describe the "rules of classrooms". Many such studies demonstrated that children at school - as one of social contexts-- were expected to learn and to interact in ways particular to that classroom. However, methodological and theoretical elaborationr were needed. In concluding, it seemed important to combine those two lines and to study communication in classrooms in more numerous types and in a wider range of age.

Key words: communication in classrooms, teacher-student interaction, ethnography, rules of classrooms, communicative competence.
\end{abstract}

子どもたちは教室の中で日々何を, どのように学んで いるのだろうか。本稿では, 「教室とは, 教師と生徒が 情報を交換する相互作用文脈である。」(Wilkinson \& Calculator, 1982),「授業も1つのコミュニケーション場 面である。」(東, 1984) という視点に立ち、コミュニケー ションの特徴・性質等から, 教室内での教授一学習を考 えたい。

教室におけるコミュニケーション研究は, 大きく 20 の流れにまとめることができる。第 1 は, 教授行動の中 心としての発話に焦点をあてる研究である。教室では教 科書あるいは板書など書きことばも重要な位置を占める が，しかし，これらは口頭によるやりとりの中で教材と して，あるいはまとめとして用いられて始めて生きてく る。したがって, 教室内でどのように教授一学習が行わ

\footnotetext{
* 本稿をまとめるにあたり，御茶の水女子大学家政学部無藤 隆助教授・国学院大学文学部斎藤こず总助教授飞文献上の示 唆をうけました。また，無藤先生には，草稿の段階で貴重な 助言をいただきました。お二人に記して感謝いたします。 ** 中央大学非常勤 (Chuo University)
}

れているのかを明らかにしょうとすれば，教師・生徒の 発話への着目は当然のこととなる。これに対して, 近年, いわゆる教科内容の教授一学習を支えるものとして，あ るいは密接不可分なものとしての様々な教室ルールが明 らかにされはじめている。学校・教室という学習の場を 1 つの社会的文脈と考え, 子どもたちが教室社会の様々 なルールをいかに学び (学べず), いかに実行しているか （実行に失敗しているか）を明らかにしようとするものであ る。コミュニケーションレベルでの教室ルールに着目す るのが第 2 の研究の流れである。

以下, 2 つの流れについて概括を行い, 今後の研究の 方向・課題を探りたい。その際, 教室コミュニケーショ ンの特徵・性質として何が明らかになってきたかといら 研究の結果とともに, どのような分析枠組・方法で教室 コミュニケーションへのアプローチが行われているのか について検討することにも重点を置きたい。

\section{I . 教授行動の中心としての発話}

教室内の教育の特徴を教師一生徒の相互関係からとら 
えようとする試みは古くから行われていたが，それらは， 教師の子どもへの接し方が支配的か・民主的か (Anderson 1939), 教室運営が教師中心か・子ども中心か (Withall 1956) という問題を行動観察法により検討していた。

こうした問題意識の延長として，発話記録から教室全 体の雾囲気を検討したのが Flanders (1970) である。 Flanders は, 教室での言語的相互作用が教師により開 始されるか, 生徒により開始されるかをチェックするこ とにより, 教室の雾囲気の傾向をとらえようとした。チ ェックに際しては, 10のカテゴリー（教師の発話一感情受 容, 賞賛あるいは勇気づけ, 生徒のアイディアの受容あるいは 使用, 質問, 講義, 指示, 批判あるいは権威の正当化 : 生徒の 発話一応答, 主導 : 沈黙あるいは混乱) を設定した。日本で も Flanders の影響をうけた研究は数多くなされている （岸1981，松田他1976，1977，1978，1979，1980，1981，1982, 1983，1984，塚田1979，1980，1982，1983a,b，塚田・酒井・岸 1976)。

また, Flanders と同じ頃, 教授行動の科学的分析を 目的として Smith・Meux C Coombs·Eierdam \& Szoka (1962), Bellack $\cdot$ Kliebard·Hyman \& Smith (1966) が 各々分析枠組を提出した。Smith らは, やりとりの論理 的特徴に基ゔき13のカテゴリー（定義, 記述, 指摘, 陳述, 報告, 置換, 評価, 意見, 分類, 比較および対照, 条件的推論, 説明，教室を方向つけ管理すること）を設定した。このカテ ゴリーを参考にした日本の研究には多田・岡田・伊藤 （1976）がある。一方, Bellack らは教室発話を教授学的 意味 (構造づけ, 誘い, 応答, 反応) - 話の内容 (題材的意 味, 題材一論理的意味, 指導的意味, 指導一論理的意味) - 話 し手は誰か等を組合わせて分析した。

このように, Flanders·Smith ら・Bellack らそして その影響を受けた研究者により, 教室発話はカテゴリー 化して分析され, 教室全体の雲囲気・教授法の傾向はつ かめるようになった。従来漠然とした印象により記述さ れていた教授法に科学的基礎が提供された（Gage，1978） といってもよいだろう。しかしながら,これらのカテゴ リー化にはいくつかの問題点がある。以下, 問題点をあ げるとともに，その克服をめざした分析枠組を紹介する。

第 1 に, Flanders·Smith ら・Bellack らに共通する 問題点として, 発話を直前直後のつながりでのみとらえ るマルコフ過程に基づいた枠組を用いている点があげら れる。教室場面では, 個々の発話は 1 つつばらばらに 存在するのではなく, 1 授業時間・あるいはいくつかの授 業時間にわたって 1 つまをまりを構成していることを 考えると, マルコフ過程に基づく枠組では授業全体の中 での各発話の位置がとらえられない。この点を克服する
枠組としては, Sinclairを中心とする Birmingham 大 学グループの階層尺度モデル (rank scale model) がある (Sinclair \& Coulthard, 1975)。Sinclair らは, Halliday （1961）の文法階層尺度にヒントを得て， act（意味の最小 単位), 一 move ( 1 発話：1つ以上の acts からなる)-exchange (相互作用の 1 単位: 基本構造は主導・応答・追随の 3 moves からなる) - sequence (同種・繰り返しの exchanges からなる) 一transactions（いくつかの sequences, exchanges を含む) -lesson（授業全体）という階層モデルを 設定して, 教室発話の構造化を行った。Sinclair らは, 文法モデルを採用することにより, 授業全体が構造化で きるとともに, どんな内容の授業についても同様に分析 可能としている。

第 2 の問題点としては, Bellack ら以外の Flanders, Smith らでは, 何についての発話であるかをとらえうる 枠組となっていない。教室内の発話の特徴としては, 常 にその背後に「課題」が存在するということがあげられ る。教師と生徒は, 知的あるいはその他の教育目標に到 達すべく「課題=具体的な教材・題材」をめぐってやり とりを交わす。したがって，「課題」を組み込んだモデ ルの構築が不可欠となり, どのように「課題」を組み込 むかが重要となる (Griffin, Cole \& Newman 1982)。

Bellack はこれを, 題材としての意味・題材の扱いに 含まれる認知過程 (題材一論理的意味) ・ 指導上の意味・指 導上の意味をどのように扱うか（指導一論理的意味）の 4 側面からチェックしたわけであるが, そのカテゴリーは 平面的・羅列的であり体系的でなかった（佐々木 1977）。

これに対して, 教師の抱いている知的目標の水準に発 話を対応づけることにより, 教室発話を体系化しようと する枠組に, Blank, Rose \& Berlin (1978), Collins \& Stevens (1982) がある。たとえば, Blank らは, 課題の 対象からの知覚的情報と言語との距離 (perceptual一language distance) という抽象化の程度で分析枠組をつくっ た。この枠組によれば, 同じ対象を前にした質問でも, 「これらの名前は？」と尋ねた場合と「これらの共通点 は?」と尋ねた場合とでは, 後者の方が前者よりも話さ れている対象と子どもを対象の分析へと導く教師の発話 との間の距離が遠い, つまり抽象化の程度が高いという ことになり, 子どもにとって異なる知的活動を要求する ことが示せることになる。しかしながら，ここでいう

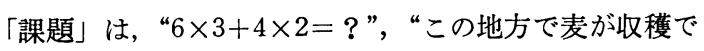
きないのはなぜか?”などの単一・単純明快なものであ る。第 1 の問題点でも述べたが, 授業では 1 時間あるい は数時間がまとまりになることも珍しくない。「課題」 の面でも授業全体を構造化できるモデルが必要であろう。 
この授業全体の課題面からの構造化に際しては, Dore, Gearhart \& Newman (1978) の時間的組織化の 指摘が参考になる。Dore らは, 教師が課題を計画する 際の 2 側面として, 成分 (参加者・手続・場所・スケジュー ル）と時間的組織化（設定・遂行・終了）を指摘した。こ れによれば, 1 つの課題を遂行するためには, その準備 段階（設定）があり，遂行後は評価や片付けなどの 終了 段階が必要であることになる*。この指摘にヒントを得 て, 幼児教育場面の課題（30～60分位のまとまり）の構 造 に対応させる形で発話を分析した研究としては, Muto (1982) ・藤崎 $(1983$ ・1985), 藤崎・無藤（1985）がある。 これらの研究では, 課題全体が構造化され, 教師の経験 差による課題構造のちがい・子どもの年齢による課題構 造のちがいが検討された。

また, Sinclairらは, 何についての発話かという問題 については, 教師が教室内で行う仕事の 3 つの領域とし て教科内容・教科の組織化 (今の内容を前後の内容と結びつ ける)・集団としてやっていくための訓育面を指摘して いる (Sinclair \& Brazil 1982)。ただし， 3 領域と先述の 階層モデルとは関係がつけられていない。

現在のところ，何についての発話なのかという点につ いては, 知的目標のレベル・時間的組織化・教師の仕事 の領域の種類というようにいくつかの側面が指摘されて きている。これらすべてを含めた枠組の作成が可能なの か, あるいはすべてを記述できるわけではないならどこ に焦点を合わせるのか, 今後の検討課題である。

第 3 の問題点としては, Flanders·Smith ら・Bellack らの枠組では, 生徒によるやりとりの差を扱ってこなか ったという点がある。通常, 授業は 1 人（あるいは少数） の教師対多数の生徒という形で展開することが多い。し かし，いわゆる一斉授業の際にも生徒に応じて教師一生 徒間のやりとりは変化する。この変化を扱いうることが, 理論的にも実践的にも必要であろう。この点については, Sinclair らの枠組でもあまり考虑されていない。むしろ, Blank ら・Collins らの枠組の方が, 生徒別にやりとり される質問等のレベルを検討することが可能である。

生徒の個人差を扱うことに重点を置く研究としては, 期待効果実現の過程をやりとりの面から検討しようとし た Brophy \& Good (1970), Cooper $\cdot$ Hinkel \& Good (1980), Cooper (1985), Good·Cooper \& Blakey (1980) がある。しかし, これは, やりとり以前に教師の期待が 存在するわけであり, あくまでも主導権は教師にある。 生徒の側がやりとりで果たす役割・教師に与える影響に ついては，まだ十分な検討がなされていない。わずかに， Collins \& Stevens (1982) が対話をコントロールする要
因の 1 つとして, 教師の抱く生徒モデルを導入している 程度である。生徒側をどう分析枠組に組み込んでいくか が, 今後の重要な課題であろう。

\section{II .コミュニケーション面での教室ルール}

教室での教師一生徒のやりとりは, いわゆる教科内容 についてのみなされるのではない。教授一学習の成立を 可能にする教室社会をつくり出すやりとりも重要である。 こうした社会集団で生活する方法を記述する研究として エスノグラフィー (ethnography) と呼ばれる研究の流れ がある (Heath 1982 a)。元々人類学に端を発し (Dobbert 1981), 社会学からも影響をうけてきたエスノグラフィ 一の研究レベルは, 社会システム・文化を含む広範囲に わたっているが**, 今回は教室におけるコミュニケーシ ヨンレベルの研究に絞って概観する。

教室でのエスノグラフィ一研究は, 一般的な教授技術 よりも, 特定のクラス内での生活の複雑さや微妙さを検 討することに興味があり, 出来事の記録を詳細に分析し て教室内の言語や生活を形成するパターンや暗黙のルー ルは何かを明らかにしようとする(Woolfolk, 1985)。特に， 客観的な明文化されたルールではなく, 参加者にとって のその状況の意味・参加者の意図等を理解することが強 調される (Measor \& Woods 1983)。その際, 参与観察を 中心として, ビデオテープレコーダ・オーディオテープ レコーダー等の機械, インタヴュー, 質問紙, 既成の資 料 (教科書・カリキュラム・生徒の作品等) 等, 多様な方法・ 情報源を用いており(Wilcox $1982 \mathrm{a}$ ), また, 分析に際し ては, 言語学・社会学をはじめ様々な研究領域の成果を 取り入れている***。

教室でのコミュニケーションレベルのエスノグラフィ 一研究は, 研究者により文脈分析 (McDermott 1977, McDermott・Gospodinoff \& Aron 1978)・ミクロエスノグラフ ィー(Erickson $1982 \mathrm{a}) ・$ 構成的エスノグラフィー（Mehan 1978・1982）と色々展開されているが, それらに共通す る特徴は教室内でのやりとりの徹底した詳細な分析であ る。近年はビデオテープレコーダー等を利用することに より, 秒単位での分析も可能になった (McDermott 1977, Wallat \& Green 1982, Green \& Weade 1985)。分析に際し ては, (1)分析データをできるだけ元に近い形で呈示する。

* ただし, Dore らは, 発話をカテゴリーに分類する際には この組織化の考えは取り入れず，むしろ speech actの考え を取り入れた conversational actを提出している。

** エスノグラフィーの研究史については, Hymes (1982)・ 江淵 (1982) 参照。

*** 研究法の text book としては, Dobbert (1981) がある。 
(2)ある部分たとえば予測に合わない部分を例外として片 ゔけることなく，すべてを分析する。(3)分析は参加者の 意味づけについてなされ, 実際の行為の流れから確認さ れる。(4)分析を相互作用のレベルで行う (Mehan 1978)。

以下, 主な研究を整理する。

\section{(1) 学校言語と家庭言語}

学習の場における教師・生徒相互の誤解・フラストレ ーション, それに伴ら学習の中止の問題を扱うことを目 的としたコミュニケーションレベルのエスノグラフィー 研究の重要性を提唱したのは社会言語学者の Hymes (1972, 1974) である。Bernstein (1971) の言語コード仮 説を背景として, 当初の主な研究テーマは, 学校と家 庭・地域との言語的不連続性にかかわるものであった。

Tough (1976) $\cdot$ Wells \& Montgomery (1981) $\cdot$ Feagans (1982) - Wells (1983) は, 学校言語と minority らの家 庭言語の相違点を, 価值 (目標)・語彙・談話スタイル・ 相互作用パターン等について明らかにしている。たとえ ば, Wells (1983) によれば, 相互作用パターンに関して, 家庭では子どもがしばしばやりとりの主導者になるのに 対して学校では教師が主導者となる。さらに, 家庭での やりとりはその時々の興味から始まるのに対して, 学校 ではカリキュラムに基づいた目標に即してやりとりがな される, という。

また, 近年は, 日々の多様な社会状況においてうまく やりとりするには，音韻・語彙・文法をこえたコミュニ ケーションレベルの知識が必要であるとして, コミュニ ケーションの有能さ (communicative competence) が重視 されている(Hymes 1974, 1979, Gumperz \& Gumperz 1982, Enright \& Gomez 1984)。コミュニケーションの有能さの カテゴリーとして, Black (1979) は状況の変化への適応 可能性・非言語面での適切さ・やりとりのきまりや条件 を知っていること・前後の出来事との関連をつけられる ことの 4 種をあげ，また，Lazarus (1984) は言語使用 の規則性に対するメ夕言語的認識・混乱や問題を指摘す る能力・目的に合わせて話し方を巧妙に変えることの 3 種をあげている。

こうした研究により, 子どもの学校への不適応の責任 は, 個々の子どもから学校一家庭といら社会過程へと移 行したといえよう。

しかし, 不連続性の視点に立つ研究では人々が漠然と 抱いていた不連続感を再強化したのみであり, 加えて解 決をコミュニケーションの有能さなど子どもの頭にある ことを変えることに求めるかぎりあまり成果望めない (Gilmore \& Smith 1982) として, むしろ両者の連続性を 重視する研究・あるいは両者の差を文脈のちがいとみる
研究がある。前者の例として, MacLure \& F rench （1981）は, 家庭と学校でのやりとりを比較して, やりと り開始の権利が教師にかたよっている点などのちがいは あるものの, 両者のやりとりの構造は共通していること を示唆した。後者の例としては, Mercer \& Edwards (1981) の研究がある。Mercer らは, Cole \& Scribner (1974) の行ったクペル族の学校課題と生活課題の出来の ちがい,つまり同じ知的構造をもつ課題でもそれが生活 場面に埋め込まれているか否かで異なる遂行結果を生む ことを示した研究に影響を受けて, 学校と家庭との社会 的文脈のちがいに不適応の問題を位置つけた。これは, 子ども側の不正確な欠陥がある遂行と, 社会的文脈のち がいによる教師一生徒間の相互理解の不足とを区別する ことを主張するものである。同様に文脈のちがいに着目 する Heath (1982b) は, 形としては疑問文だが実用上 は指示的である発話に答えることに慣れていない，答の 既にわかっている質問や本からの情報について尋ねる質 問に慣れていない子どもへの対策として，学習環境つま り教師の言語的対応を変えるところまで研究として行っ ている。

\section{(2) 隠れたカリキュラム}

社会的文脈に注目する研究者は, 「子どもは学校とい う 1 つの社会的文脈の中で, ある一定のやり方で学習す ること,やりとりすることが望まれている」(Shultz, Florio \& Erickson 1982) と指摘する。こうした教室ルー ルは, 研究者により隠れたカリキュラム (Jackson 1968, Wilcox 1982b, Green \& Weade 1985), 第 2 のタイプのカ リキュラム (Green \& Harker 1982), 基礎ルール (Mercer \& Edwards 1981) 等と呼ばれている。

詳細な分析の結果, たとえば， 1 度に話すことができ るのは 1 人だけ (Wallat \& Green 1979), 教師の指名を無 視して発言すれば正しい答を言っても教師に受け入れら れない場合がある (Mehan 1979) 等のルールが示されて きている。さらに, 登園して自由にすごした後の朝の集 まりの輪の形成過程における言語と非言語的行為とのか かわりの分析 (Bremme \& Erickson 1977, Wallat \& Green 1979, Green \& Weade 1985), 読みの小グループの維持に 果たす身体的位置や姿勢の役割の分析 (McDermott, Gospodinoff \& Aron 1978), 挙手により指名される時のやり とり (McDermott 1977), 教師が生徒に物語を読んできか せる時の伝達過程 (Green \& Harker 1982, Eder 1982 a) 等 が分析された。その結果, 従来ルーティンとして片付け られてきた教室でのやりとりが実は複雑であること、ル 一ルに支配されていること等が明らかになってきた (Minuchin \& Shapiro 1983)。しかも, 子どもはルーティ 
ン遂行において受け身ばかりの存在ではなく, 子どもと 教師が各々責任を持って参加することにより教室でのや りとりがリズミカルに進行していくのである（Mehan 1982, Brause \& Mayher 1984)。

しかしながら，一方で，教師はこうしたルールを明示 することは少ない (French \& Maclure 1983)。子どもたち は，様々なルールを言語・非言語的行為・メッセージの つながり等多様な文脈化手がかり (contextualization cues : Gumperz 1982) をもとにして読み取っていかなければな らないのである(Green \& Weade 1985)。こうした文脈化 手がかりの読み取りはコミュニケーションの有能さの重 要な側面と言ってよいであろう（Erickson 1982 b)。逆に， 教師の仕事としては, 知的情報を伝えることの他に, あ るいは密接不可分なものとして, 教室コミュニケーショ ンのルールをきちんと伝えていく, あるいは子どもの持 っているルールを考慮することが重要となる。

また最近, 読みの能力別グループでの教師一生徒の発 話を分析した結果, グループによって, 誰にどのように 順番を割りあてるか等が異なることが示された（Eder 1982b, Gearing \& Epstein 1982)。同一クラス内でも, 教 師は子どもに応じて異なるルールを用いてやりとりをし ている可能性がある。こうした差異が何に基ういている のか, 子どもにどのように影響を与えるのか, 今後の課 題であろう。

\section{(3) 教室エスノグラフィー研究の課題}

エスノグラフィー研究により，教授法を事前テスト・ 事後テストと関連づける従来の実験室的研究では浮かび あがってこなかった教育の側面が検討されるようになっ てきたが，いくつかの考慮すべき点もある。

第 1 は方法上の問題である。エスノグラフィーの中で も近年の教室エスノグラフィーでは, ビデオテープレコ ーダーを使用することにより詳細な記述を行うことが中 心となりつつある。詳細な記述はビデオの使用により初 めて可能になったが, 万能ではない。何台ものビデオカ メラを教室に持ち込むことは現実的に不可能である。そ こで通常, 教師と教師にかかわる子どもに焦点が向けら れるわけだが，この場合でも教師の姿は記録されるが教 師が何を見ているかは正確には録れない。また，機械を 通さず人間が直接みた方が, 色々な方面をみたり, 色々 なことを感じとれるのも事実である（ェスノグラフィーで は, ビデオ等で哣録する場合です必ず研究者自身がその場にい ることが原則となっている)。フィールドノートは, 厳密さ や信頼性を欠くということで研究の表面にはでてくるこ とが少なくなったが, 今後は, ビデオ記録の解釈, 分析 を支える重要な資料として再評価する必要があろう。ま
た，教師・生徒に直接，何を見・何のつもりである場面 である行動をしたのかを聞くこともできる。ただし，フ イールドノート・インタビューともに, その際の方法論 の確立が必要となろう（Ericsson \& Simon 1980, 1984, Hitchcock 1983, Beynon 1983, Denscombe 1983, Agar \& Hobbs 1982, Stubbs 1983)。

第 2 は, 対象選択上の問題である。エスノグラフィー 研究では徹底した詳細な分析を旨とするので, 研究労力 上その分析対象数は限られてくる。また，1つの発話・ 1つの場面をその時その時切り離すのではなく, 教室生 活全体の中でみるのであるから, その教室に熟知してい る必要があり, 長期にわたるかかわりが要求される。こ の点からも分析対象数は限られる。限られた分析対象の 結果から何を他への共通性として記述するのか。いたず らに一般化するのではなく, その教室の特性をきちんと 特定化することの方が有効であろう。このためには, よ り大きな社会文脈つまり教室がその一部となっている社 会システム等に注意を払うことが必要であろう（Mehan 1979)。

第 3 は, 記述の提出上の問題である。エスノグラフィ 一研究では収集した全資料を詳細に分析するが, 通常そ の中の 1 部分を例として提示する。この際に用いられる 例がよくある事例の 1 つなのか, 典型例なのか, 例外例 なのか等必ずしも明確にされていない。

第 4 は，エスノグラフィー研究にとって理論とは何か, という問題である (Evans 1983)。コミュニケーションの 有能さや隠れたカリキュラム等の概念が提出され, 多く の教室場面が分析されてきた。しかしながらいわゆる理 論はないし, むしろ理論化を避けて徹底した記述をめざ している。理論というよりも, 前述の概念も含めて, 教 室でのやりとりを検討する上での重要な視点を提供して いるともいえる (Gilmore \& Smith 1982)。今後は, 様々 な教師・教室場面の比較(Wilcox 1982b Au \& Mason 1983) や他のタイプの研究との補完が, 研究を topic oriented な段階から hypothesis oriented な段階へと進める上で のポイントとならう (Heath 1982a Hymes 1982)。その際, より実験的な方法を併用することも考えられる (Jacob 1979)。この例としては, 教室相互作用について子ども は何を知っているのか絵本を用いて非ねる (Willes 1981), 学校ごっこを観察する (Willes 1983), 仮設的教室を設定 して子どもにメタ言語知識を尋ねる (Wilkinson, Wilkinson, Spinelli \& Chiang 1984) がある。

\section{III. 今後の課題}

\section{（1）活動の目標}


本稿では, 教室でのやりとりに関する研究を大きく 2 つに分けて検討した。その結果, 今後研究をすすめてい く際に重視することとして，発話および発話内容を授業 全体の中に位置づける, 生徒側の要因を組み込む, 教授 一学習と教室コミュニケーションのルールとの不可分性 を考慮する，等が確認された。

Green \& Weade (1985) は, 教室内での相互作用の 際に同時に構築される多様な意味として, (1)学問的内容, (2)適切な社会参加への期待, (3) (1)・(2)が埋め込まれてい る活動が 何なのか（例. 語句の書取りテストをしているの か, 経験発表をしているのか, 経験発表の仕方について討 論し ているのか) の 3 種を指摘した。本稿との対応では, (1) は Bellack ら・Blank ら・Collins らの枠組で扱われて きたし，(2)については教室エスノグラフィーで扱われる ようになってきた。従来別々に研究が進められてきた(1) と(2)を結びつけ，教室でのコミュニケーションの全容を とらえるには, 今後(3)の活動の性質・活動の目標をどの ように組み入れていくかが重要なポイントとなろう。

活動・出来事の特定化については, Hymes (1974), Duranti(1985) の会話出来事モデル(speech event model) が参考になるかもしれない。Hymes らは, 会話出来事 の構成要素として, 状況・参加者・目的・行為の連な り・鍵・手段・規範・領域を指摘する。中でも目的につ いては, 社会規範・文化的期待から解釈できる目標と個 個人の目標とを区別する必要を述べている。社会規範の 担い手である教師の目標と受け手と考えられる生徒の目 標が調和しているのか, ずれているのかという視点が導 入できるかもしれない。

\section{(2) 就学前後の言語発達}

教室でのやりとりは教師の力のみで成立するのではな く，教師と子どもの共同活動の所産である(Mehan 1979)。 Schaeffer (1977) は, 大人一子ども間の相互交涉の維持 には少なくとも次の 3 点が同時におこる必要があるとい う。言語・非言語的行為を通して送られる信号の同じ意 味を共有する, 会話および活動の時間的流れに添うこと ができる（例. 話し手が, 先に述べたテーマを精緻化したけれ ば，精緻化が期待されていることをうなづきや言語を通して 確 信しなくてはならない)。相互作用を調整する暗黙の，あ るいは明示的なルールを共有する。同様のことは, 教室 での会話でも必要であろう。

では, 子どもたちは教室でのやりとりの成立・維持の ための様々な要件をいつ身につけるのであろうか。 Willes (1981) は, 小学校の新入生に入学直後と 7 か月後 に絵本を見せて，教室での相互作用に関する物語を完成 させた。その結果, 入学直後から, 教室での相互作用に
ついてよく知っている子どもとほとんど知らない子ども が混在していることがわかった。また, Blumenfeld \& Meece (1985) は, 教室ルールを知覚して行動する点にお いて, 小学校 1 年生ですでに 5 年生と同程度に有能であ ることを示した。本稿で取り上げたエスノグラフィー研 究は, そのほとんどすべてが小学 1 年生についてなされ ている。この時期，教師はどのようなルールをどのよう にして子どもに伝えているのか，子どもは何を手がかり にして理解しているのか, 検討する必要があろう。

従来, $3 \sim 5$ 歳で一応話しことばが完成すると考えら れることが多く, 学齢児の言語発達においては書きこと ばが問題とされてきた。しかしながら，3〜 5 歳で完成 するのは，具体的なことがらについて状況の文脈に頼り ながら親しい人と直接対話のかたちをとって展開する言 語活動（岡本 (1983) 流に言えば一次的ことば）である。岡 本は, 学校に入学することにより, 現実場面を離れたこ とがらについて, ことばの文脈のみで, 未知の不特定多 数を想定して, 自分で話のプロットを調整していかなけ ればならない授業のことば（二次的ことば）が出現すると している。藤崎 (1982) は, 3〜6 歳児の経験発表を分 析して, いわば一次的ことばから二次的ことばへの移行 をみた。これらは, 発話の文脈が状況の文脈なのかこと ばの文脈のみなのかという面からみた就学前後の言語発 達の指摘であるが，もう1つ，本稿で取り上げたように， 教室という社会場面での言語使用を学ぶことも学齢児の 言語・コミュニケーションの発達の焦点といってよいで あろう(Wilkinson 1982, Shuy 1979)。

教室でのコミュニケーション研究は, 教室内での教授 一学習を考える上からも, 学齢児の言語発達を考える上 からも今後詳細な検討が必要となる分野と思われる。

\section{（3） 日本の特徵, 幼児期への着目}

欧米では, 教室内に多言語を使用する子どもが混在し ていること, 特に minority に学校への不適応が多いこ とを反映して, 教室コミュニケーションのルールヘの着 目が多くなされてきた。この点に関して, 日本は一応単 一言語の国であるので問題が少ない，といえるであろう か。たとえば, 柏木・東 (1977) は母親の幼児への発達期 待・就学前教育観について, 三宅・田島・臼井 (1980) は 幼児の自由遊び場面に㧍ける母親の行動について，各々 階層差を指摘している。実際には, 家庭文化と学校文化 のギャップに悩む子どもは多いのではないだろうか。欧 米のように minority と簡単にくくれないだけにかえっ て問題が見えにくい可能性がある。

日本の教育の特徴について, 東 (1984) は, 幼児期に字 施した 2 種類の動機づけテストと小学校高学年時の学業 
成績との相関関係を日米比較して,「日本の学校教育の 中でよくやるためには，おもしろくない仕事にでもじっ くりと根気よく, 注意深く取り組む性質が必要であり, アメリカの学校でよくやるためには, そういう性質は必 要ではないけれども，興味をそそる仕事に対しては，じ っくり注意深く取り組むような態度が必要だ」と述べて いる。また, Cummings (1980) は, 参与観察の結果, アメリカと比較した日本の小学校低学年の特徴として, 毎朝教師汇挨㨑すること・机の横に立って話すこと・静 かに他の生徒や教師の話に耳を傾けること・集団生活の 中で協力し合うこと等の学級秩序の確立や, 皆の前で堂 堂と発表できるように仕向けること等が課題として教師 により集中的に取り組まれることを指摘している。こう した教育の文化比較も今後必要であろう。

また, 日本の場合, 幼稚園・保育園一の就園率が 1980 年において 4 歳児で同年齢人口の $80 \%$ ・ 5 歳児では $91 \%$ （村山 1983）ということを考えると，ほとんどの子ども が小学校入学以前に集団生活を経験している。どういう 保育形態であるにしろ, 家庭とは異なる社会文脈の中で 子どもは生活し，様々なルールを学んでいる(藤崎 1986)。 小学校生活を考える上からも，あるいはむしろ幼児期の 生活自体を考える上からも幼児教育場面でのコミュニケ ーションへの着目が今後必要であろう。

\section{引用文献}

Agar, M. \& Hobbs, J.R. 1982 Interpreting discourse: Coherence and the analysis of ethnographic interviews. Discourse Processes, 5, 1-32.

Anderson, H.H. 1939 Domination and social integration in the behavior of kindergarten and their teachers. Genetic Psychology Monographs, 21, 287-385.

Au, K.H. \& Mason, J.M. 1983 Cultural congruence in classroom participation structures: Achieving a balance of rights. Discourse Processes, 6, 145 -167 .

東洋 1984 子どもにものを教えること 岩波書店

Bellack, A.A., Kliebard, H.M., Hyman, R.T. \& Smith, F.L. 1966 The language of the classroom. 木原・加藤（訳） 授業コミュニケーションの 分析 黎明書房

Bernstein, B. 1971 Class, codes and control. Theoretical studies towards a sociology of language, 1. Routledge \& Kegan Paul. 萩原元昭（編訳） 1981 言語社会化論 明治図書

Beynon, J. $1983 \mathrm{~W}$ ays-in and staying-in : Field work as problem solving. In M. Hammersley (ed.) The ethnography of schooling: Methodological issues. Nafferton Books.

Black, J.K. 1979 Assessing kindergarten childrens' communicative competence. In O.K. Garnica \& M.L. King (eds.) Language, children and socie- ty. Pergamon Press.

Blank, M., Rose, S.E. \& Berlin, L. J. 1978 The language of learning: The preschool years. Grune \& Stratton.

Blumenfeld, P.C. \& Meece, J.L. 1985 Life in classrooms revisited. Theory into Practice, 24, 50-56.

Brause, R.S. \& Mayher, J.S. 1984 Teacher directed lessons: Organization and implications. Paper presented at the American Educational Research Association, New Orleans, LA.

Bremme, D.W. \& Erickson, F. 1977 Relationships among verbal and nonverbal classroom behaviors. Theory into Practice, 16, 153-161.

Brophy, J. \& Good. T. 1970 Teachers' communication of differential expectations for children's classroom performance: Some behavial data. Journal of Educational Psychology, 61, 365--374.

Cole, M. \& Scribner, S. 1974 Culture \& thought: A psychological introduction. 若井邦夫（訳） 文 化と思考 サイエンス社

Collins, A. \& Stevens, A.L. 1982 Goals and strategies of inquiry teachers. In R. Glaser (ed.) Advances in instructional psychology, 2 Lawrence Erlbaum Associates.

Cooper, H.M. 1985 Models of teacher expectation communication. In J.B. Dusek (ed.) Teacher expectancies. Lawrence Erlbaum Associates.

Cooper, H.M., Hinkel, G.M. \& Good, T.L. 1980 Teachers' beliefs about interaction control and their observed behavioral correlates. Journal of Educational Psychology. 72, 345-354.

Cummings, W.K. 1980 Education and equality in Japan. Princeton University Press. 友田泰正(訳) 1981 ニッポンの学校 サイマル出版会

Denscombe, M. 1983 Interviews, accounts and ethnographic research on teachers. In M. Hammersley (ed.) The ethnography of schooling: Methodological issues. Nafferton Books.

Dobbert, M.L. 1981 Ethnographic research: Theory and application for modern schools and societies. PRAEGER.

Dore, J., Gearhart, M. \& Newman, D. 1978 The structure of nursery school conversation. In K.E. Nelson. (ed.) Childrens' language, 1, Gardner Press.

Duranti, A. 1985 Sociocultural dimentions of discourse. In T.A. Van Dijk (ed.) Handbook of discourse analysis. 1. Academic Press.

江淵一公 1982 教育人類学 祖父江孝男(編) 現代の 文化人類学(2) 医療・映像・教育人類学 至文堂

Eder, D. 1982 a The impact of management and turn-allocation activities on student performance. Discourse Processes, 5, 147-159.

Eder, D. $1982^{\text {b }}$ Differences in communicative styles across ability groups. In L.C. Wilkinson (ed.) Communicating in the classroom. Academic Press.

Enright, D.S. \& Gomez, B. 1984 The identification 
and development of communicative competence in diverse classroom interactive settings. Paper presented at American Educational Research Association, New Orleans, LA.

Erickson, F. 1982 a Taught cognitive learning in its immediate environments: A neglected topic in the anthropology of education. Anthropology \& Education Quarterly, 8, 149-180.

Erickson, F. $1982^{\mathrm{b}}$ Classroom discourse as improvisation: Relationships between academic task structure and social participation structure in lessons. In L.C. Wilkinson (ed.) Communicating in the classroom. Academic Press.

Ericsson, K.A. \& Simon, H.A. 1980 Verbal reports as data. Psychological Review, 87, No. 3, 215 -251 .

Ericsson, K.A. \& Simon, H.A. 1984 Protocol analysis: Verbal reports as data. The MIT Press.

Evans, J. 1983 Criteria of validity in social research : Exploring the relationship between ethnographic and quantitative approaches. In $M$. Hammersley (ed.) The ethnography of schooling : Methodological issues. Nafferton Books.

Feagans, L. 1982 The development and importance of narratives for school adaptation. In L. Feagans \& D.C. Ferran (eds.) The language of children reared in poverty.- Implications for evaluation and intervention. Academic Press.

Flanders, N.A. 1970 Analyzing teaching behavior. Addison-Wesley.

French, P. \& Maclure, M. 1983 Teachers' questions, pupils' answers: An investigation of questions and answers in the infant classroom. In $M$. Stubbs \& H. Hillier (eds.) Readings on language, schools and classrooms. Methuen.

藤崎春代 1982 幼児の報告場面に抢ける計画的構成の 発達的研究, 教育心理学研究, 30, 54-63.

藤崎春代 1983 幼児教育場面における保育者の援助： 異年令児混合の製作場面の検討 日本教育心理学会 第25回総会発表論文集, $544-545$.

藤崎春代 1985 一斉保育における子どものちがいに応 じた保育者の援助一一專例的検討 日本保育学会, 第33回大会研究論文集, 268-269.

藤崎春代 1986 一斉保育 無藤隆・内田伸子・斎藤こ ず急（編）子ども時代を豊かに-D.-新しい保育心理 学 学文社

藤崎春代・無藤隆 1985 会話能力の獲得への援助一 幼児教育場面での分析 昭和 $57 \cdot 58 \cdot 59$ 年度科学研 究費補助金特定研究(1)「言語の標準化」研究成果報 告書

Gage, N.L. 1978 The yield of research on teaching. Phi Delta Kappan, 59, 229-235.

Gearing, F. \& Epstein, P. 1982 Learning to wait : An ethnographic probe into the operations of an item of hidden curriculum. In G. Spindler (ed.) Doing the ethnography of schooling. Holt, Rinehart and Winston.

Gilmore, P. \& Smith, D.M. 1982 A retrospective discussion of the state of the art in ethnography and education. In P. Gilmore \& A.A. Glatthorn Children in and out of school: Ethnography and education. Center for Applied Linguistics.

Good, T.L., Cooper, H.M. \& Blakey, S.L. 1980 Classroom interaction as a function of teacher expectations, student sex, and time of year. Journal of Educational Psychology, 72, 378385.

Green, J.L. \& Harker, J.O. 1982 Gaining access to learning: Conversational, social, and cognitive demands of group participation. In L.C. Wilkinson (ed.) Communicating in the classroom. Academic Press.

Green, J. \& Weade, R. 1985 Reading between the words: Social cues to lesson participation. Theory into Practice, 24, 14-21.

Griffin, P., Cole, M. \& Newman, S. 1982 Locating tasks in psychology and education. Discourse Processes, 5, 111-125.

Gumperz, J.J. 1982 Discourse strategies. Cambridge University Press.

Gumperz, J.C. \& Gumperz, J.J. 1982 Communicative competence in perspective. In L.C. Wilkinson (ed.) Communicating in the classroom. Academic Press.

Halliday M.A.K. 1961 Categories of the theory of grammar. Word, 17, 241-292.

Heath, S.B. $1982^{a}$ Ethnography in education: Defining the essentials. In P. Gilmore \& A.A. Glatthorn (eds.) Children in and out of school: Ethnography \& education. Center for Applied Linguistics.

Heath, S.B. $1982^{\mathrm{b}}$ Questioning at home and at school: A comparative study. In G. Spindler (ed.) Doing the ethnograpy of schooling. Holt, Rinehart and Winston.

Hitchcock, G. 1983 Field work as practical activity : Reflections on fieldwork and the social organisation of an urban open-plan primary school. In M. Hammersley (ed.) The ethnography of schooling : Methodological issues. Nafferton Books.

Hymes, D. 1972 Models of the interaction of language and social life. In J. J. Gumperz \& D. Hymes (eds.) Directions in sociolinguistics: The ethnography of communication. Holt, Rinehart and Winston.

Hymes, D. 1974 Foundation in sociolinguistics : An ethnographic approach. University of Pennsylvania press.

Hymes, D.H. 1979 Language in education : Forward to fundamentals. In O.K. Garnica \& M.L. King (eds.) Language, children and society. Pergamon Press.

Hymes, D. 1982 What is ethnography ? In P. Gilmore \& A.A. Glatthorn (eds.) Children in and out of school: Ethnography and education. Center for Applied Linguistics. 
Jackson, P.W. 1968 Life in classrooms. Rinehart \& Winston.

Jacob, E. 1982 Combining ethnographic and quantitative approaches: Suggestions and examples from a study on Puerto Rico. In P. Gilmore, $\&$ A.A. Glatthorn (eds.) Children in and out of school: Ethnography and education. Center for Applied Linguistics.

柏木恵子・東洋 1977 日米の母親における幼児への発 達期待及び就学前教育観 教育心 理学 研 究, 25, $242-253$.

岸俊彦 1981 教授学習過程の研究——教師・览童間の 発言関連の類型 教育心理学研究, 29, 1-9.

Luzarus, P.G. 1984 What children know and teach about language competence. Theory into Practice, 23, 225-231.

McDermott, R.P. 1977 Social relations as contexts for learning in school. Harvard Educational Review, 47. 198--213.

MacLure, M. \& French, P. 1981 A comparison of talk at home and school. In G. Wells \& $\mathrm{M}$. MacLure (eds.) Learning through interaction : The study of language. Cambridge University Press.

McDermott, R.P., Gospodinoff, K. \& Aron, A. 1978 Criteria for an ethnographically adequate description of concerted activities and contexts. Semiotica, 24, 245-275.

松田伯彦・松田文子 1982 教師の経験差による教授行 動の差異 日本教育心理学会第24回総会発表論文集, $720-721$.

松田伯彦・松田文子 1983 教師の経験差による教授行 動の差異(2) 日本教育心理学会第25回総会発表論文 集, 536-537.

松田伯彦・松田文子 1984 教師の経験差による教授行 動の差異(3) 日本教育心理学会第26回総会発表論文 集, $582-583$.

松田伯彦・松田文子 - 西村正司 - 金納善明 -上杉賢士 塚本充 1980 教師と教育実習生の教授行動 (16)(19), 日本教育心理学会第22回総会発表論文集, 694 -701 .

松田伯彦・松田文子・金納善明・上杉賢士・小川 麻 有 美・石井和生・宮野祥雄 1977 わかる授業の教育 心理学的研究 $1 \sim 5$. 日本教育心理学会第19回総 会発表論文集, 586-595.

松田伯彦・松田文子・金納善明 -上杉賢士・塚本充 - 中 塚勝俊・丸栄一 1981 教師の経験差と教授行動 $1 \sim 4$. 日本教育心理学会第23回総会発表論文集, $726-733$.

松田伯彦・松田文子・丸栄一・金納善明 - 上杉賢士・石 井和生・宮野祥雄 1978 わかる授業の教育心理学 的研究 $6-10$. 日本教育心理学会第20回総会発表 論文集，568一 577 .

松田伯彦・松田文子・金納善明・上杉賢士・宮野祥雄・ 西村正司・石井和生・塚本充 1979 教師と教育実 習生の教授行動(11)一(15) 日本教育心理学会第21回総 会発表論文集, $726-735$.

松田伯彦・丸栄一・松田文子・金納善明 - 上杉賢士 ・宮
野祥雄 - 小川麻有美 - 石井和生 - 高梨泰 1976 教 師と教育実習生の教授行動(5)一(10) 日本教育心理学 会第18回総会発表論文集, 576-587.

Measor, L. \& Woods, P. 1983 The interpretation of pupil myths. In M. Hammersley (ed.) The ethnography of schooling : Methodological issues. Nafferton Books.

Mehan, H. 1978 Structuring school structure. Harverd Educational Review, 48, 32-64.

Mehan, H. 1979 Learning lessons: The social organization of classroom behavior. Harvard University Press.

Mehan, H. 1982 The structure of classroom events and their consequences for student performance. In P. Gilmore \& A.A. Glatthorn (eds.) Children in and out of school. Center for Applied Linguistics.

Mercer, N. \& Edwards, D. 1981 Ground-rules for mutual understanding: A social psychological approach to classroom knowledge. In N. Mercer (ed.) Language in school and community. Edward Arnold.

Minuchin, P.P. \& Shapiro, E.K. 1983 The school as a context for social development. In P.H. Mussen (ed.) Handbook of child psychology, 4, John Wiley \& Sons.

三宅和夫・田島信元・臼井博 1980 自由遊び場面にお ける母子相互交涉と幼児の知的発達—— 日米比較 研究 北海道大学教育学部紀要, $37,1-76$.

村山祐一 1983 現代の保育所 - 幼稚園 青木書店

Muto, T. 1982 Nursery education as a goal-directed activity. Seishin Studies 60. 95-121.

岡本夏木 1983 小学生になる前後 岩波書店

佐々木俊介 1977 授業分析における概念について I 筑波大学教育学系論集 $1,93-108$.

Schaeffer, R. 1977 Mothering 矢野喜夫・矢野のり子 （訳）母性のはたらき サイエンス社

Shultz, J. J., Florio, S. \& Erickson, F. 1982 Where's the floor?: Aspects of the cultural organization of social relationships in communication at home and at school. In P. Gilmore \& A.A. Glatthorn (eds.) Children in and out of school. Center for Applied Linguistics.

Shuy, R.W. 1979 On the relevance of recent developments in socioliguistics to the study of language learning and early education. In O.K. Garnica \& M.C. King (eds.) Language, children and Society. Pergamon Press.

Sinclair, J.M. \& Brazil, D. 1982 Teacher talk. Oxford University Press.

Sinclair, J.M. \& Coulthard, M.R. 1975 Towards an analysis of discourse. Oxford University Press.

Smith, B.O., Meux, M., Coombs, J., Eierdam, D. \& Szoka 1962 A study of the logic of teaching. University of Illinois Press.

Stubbs, M. 1983 Discourse analysis: The sociolinguistic analysis of natural language. The Univer- 
sity of Chicago Press.

多田俊文 - 岡田裕 - 伊藤顕 1976 教授行動の分析次元 （I ）・（II） 日本教育心理学会第18回総会発表論文 集, 532-535.

Tough, J. 1976 Listening to children talking: A guide to the appraisal of children's use of language. Ward Lock Educational.

塚田紘一 1979 教師の言語行動と生徒の学力および学 級適応との関係 日本教育心理学会第21回総会発表 論文集 $740-741$.

塚田紘一 1980 教師の言語行動と生徒の教師認知との 関倸 日本教育心理学会第22回総会発 表 論 文集, 662-663.

塚田紘一 1982 教師の対個人的言語行動と生徒の学力 及び教師認知との関係 日本教育心理学会第24回総 会発表論文集, 718-719.

塚田紘一 $1983^{\mathrm{a}}$ 教師の対個人的言語行動と生徒の学 級適応の関係, 日本教育心理学会第25回総会発表論 文集，538-539。

塚田紘一 $1983^{\mathrm{b}}$ 教師一生徒の言語的相互作用の 研 究 (1) : 言語的相互作用 pattern の安定性と学力の伸び との関係, 明星大学人文学部研究紀要, 19, 71-89.

塚田紘一・酒井清・岸俊彦 1976 授業分析の方法に関 する一試案 (I )・(II)・(III) 日本教育心理学会第18 回総会発表論文集, 536-541.

Wallat, C. \& Green, J.L. 1979 Social rules and communicative contexts in kindergarten. Theory into Practice, 18, 275-284.

Wallat, C. \& Green, J. 1982 Construction of social norms by teacher \& children: The first year of school. In K.M. Borman (ed.) The social life of children in a changing society. Lawrence Erlbaum Associates.

Wells, G. 1983 Talking with children: The complementary roles of parents and teachers. In $M$. Donaldson, R. Grieve \& C. Pratt (eds.) Early childhood development \& education.

Wells, G. \& Montgomery, M. 1981 Adult-child interaction at home and at school. In P. French \& M. Maclure (eds.) Adult-child conversation. CROOM HELM LONDON.

Wilcox, K. 1982 a Ethnography as a methodology and its application to the study of schooling: A review. In G. Spindler (ed.) Doing the ethnograpy of schooling. Holt, Rinehart and Winston.

Wilcox, K. $1982^{\mathrm{b}}$ Differential socialization in the classroom: Implications for equal opportunity. In G. Spindler (ed.) Doing the ethnography of schooling. Holt, Rinehart and Winston.

Wilkinson, L.C. 1982 A sociolinguistic approach to communicating in the classroom. In L.C. Wilkinson (ed.) Communicating in the classroom. Academic Press.

Wilkinson, L.C. \& Calculator, S. 1982 Effective speakers: Students' use of language to request and obtain information and action in the classroom. In L.C. Wilkinson (ed.) Communicating in the classroom. Academic Press.

Wilkinson, L.C., Wilkinson, A.C., Spinelli, F. \& Chiang, C.P. 1984 Metailnguistic knowledge of pragmatic rules in school-age children. Child Development, 55, 2130-2140.

Willes, M. 1981 Learning to take part in classroom interaction. In P. French \& M. MacLure (eds.) Adult-child conversation. CROOM HELM LON DON.

Willes, M.J. 1983 Children into pupils : A study of language in early schooling. Poutledge \& Kegan Paul.

Withall, J. 1956 An objective of a teacher's classroom interactions. Journal of Educational Psychology, 47, 203-212.

Woolfolk, A.E. 1985 Research perspectives on communication in classrooms. Theory into Practice, 24, 3-7.

（1986年 2 月 24 日受稿） 